\title{
Antiglioma Potential of Flavonoides
}

\section{Silvia Lima Costa*}

Laboratory of Neurochemistry and Cellular Biology, Department of Biochemistry, Institute of Health Science, Federal University of Bahia Universidade Federal da Bahia, Salvador, BA, 40.110-902, Brazil

The malignant gliomas are primary brain tumors and represents about $78 \%$ of all malignant tumors of the central nervous system [1]. The majority of these tumors are considered as high-grade tumors according to the current classification of the World Health Organization (grades III and IV) when diagnosed. Glioblastoma (GB) is the most aggressive form of gliomas, and is highly infiltrative and is morphologically very heterogeneous. Currently, the protocol adopted for the treatment of glioblastoma is based on surgery followed by radiation therapy and chemotherapy. Despite recent advances in the therapy of malignant gliomas with the introduction of new therapeutic agents as temozolomide [2] and antibody antiangiogenic therapy against thevascular endothelial growth factor (VEGF) [3] the median survivaltime for glioblastoma patients is still around 14 months [2]. Therefore, compounds that show antitumoractivity may be key allies to improve the conventionaltreatment applied to tumors of the CNS.The search for alternative drugs for therapeutic interventionsagainst brain tumors has shed light on phytochemical drugs.

A group of molecules that have raised interest in the scientific community are flavonoids present in different genera of plants, taking into account the diversity of biological effects, including antitumor activity [4]. Flavonoids are secondary metabolites of a large number of plants adopted in popular medicine, and protect them against the damaging effects caused by UV-radiation and microbial infectious. The basic flavonoid structure is the flavan nucleus, which consists of 15 carbon atoms arranged in three rings (C6-C3-C6), labeled A, B, and $\mathrm{C}$, which consist of two aromatic carbon rings, benzopyran (A and C rings) and benzene (B ring), and can be divided into six subgroups based on the degree of the oxidation of the C-ring, the hydroxylation pattern of the ring structure, and the substitution of the 3-position: flavonols, flavones, flavones, flavanones, flavanols, anthocyanidins. In vitro and in situ blood brain barrier (BBB) studies have been reported that flavonoides can cross the $\mathrm{BBB}$ with considerable variation in permeability for different flavonoides depending on its structure $[5,6]$. However the sensitive of cerebral tissue tonaturally occurring flavonoides and synthetic derivatives have been poorly considered and little is known about their pharmacological potential for therapy of malignant gliomas.

In vitro and in vivo have been investigated the anti glioma effect of extracts containing flavoinoids and purified molecules obtained from different plant species around the word (Table 1). The inhibition of growth and induction of apoptosis of glioma cell lines weredemonstrated by Scheck and collaborator (2006) after treatment of human malignant brain tumor cells with extracts derived from the mature roots of Scutellaria baicalensis. Flavonoids present in Vaccinia macrocarpa (blackberry) induced inhibition of cell proliferation, growth arrest, and apoptosis in the human glioblastoma cell line U87 [7]. The anticancer activity of extracts derived from the mature roots of Scutellaria baicalensis on human malignant brain tumor cells was observed by Scheck and collaborators (2006). An antiproliferative effect of quercetin in the human U138MG glioma cell line was also demonstared by Braganhol et al. [8]. Purified flavonoid Kaempferol induced apoptosis in glioblastoma cells through oxidative stress [9] and purified silibinin sensibilizated human glioma cells to TRAILmediated apoptosis via DR5 Up-regulation and down-regulation of c-FLIP and surviving [10]. The ability of four flavonoides (5-hydroxy7,4-dimethoxyflavone, casticin, apigenin, and penduletin)isolatad from Croton betulaster to inhibit growth of GL-15 human glioblastoma cells and down regulate proangiogenic cytokinetransforming growth factor- $\beta 1$ (TGF- $\beta 1$ ) was also demonstrated [11]. The flavonoid rutin, extracted from Dimorphanda mollis, a Brazilian shrub adopted in popular medicine, and its derivatives have been adopted for the treatment of senile cerebral defects, to relieves micro trauma on tissue and also have pharmacological application to strengthen veins, thus preventing bleeding $[6,12,13]$. The potential of rutin to induces growth inhibition and apoptosis of GL-15 cells glioblastoma cells was also evidenced [14] as well as down regulation of angiogenic cytokine VEGF and TGF- $\beta 1$ [11]. The magnitude of anti-tumoral effect of flavonoids tested against glioblastoma has been related to flavonoides structure, especially to the degree of hydroxylation and methylation. In a study conducted by the group of Costa SL (2012, data not published) comparing the effects of polyhydroxylated flavonoides it wasobserved that amongst the flavonoids studied, 3',4'-dihydroxyflavone and 3,4',5,7-tetrahidroxiflavone (kaempferol) showed an expressive reduction in filopodias, structures essential for migration, on the cellular surface, suggestinga possible association between the hydroxylated groups in carbons C3' and C4' and the antistumor effect of polihydroxylated flavonoids. Moreover, in a screening comparing the antitumor potential of ninehydroxylated and four methoxylated flavonoides the same group also observed that U251 glioblastoma cell line and TG-1 neuroglialstem cell enriched line [15] were more sensible to the polyhydroxilated flavonoid Hinokiflavone and to the polymethylated and polyhydroxylated flavonoid 8-methyl-crisiliol (8-methyl-3',4',5-trihydroxi-6,7-dimethoxyflavone)indicating that both chemical functions are related to antiglioma activity.

Moreover a mophogenic effect has been also demonstrated after exposure of human glioblastoma cells to flavonoids (Figure 1). Exposure of GL-15 cell to rutin and penduletin also induced changes on pattern of expression of cytoskeletal proteins with reduction on expression of nestin and vimentin, and increase on expression of GFAP, a marker of astrocytes, suggesting induction of astroglial differentiation $[14,16]$. Nestin is Vimentin is the major cytoskeletal

*Corresponding author: Prof. Silvia Lima Costa, VMD, MSc, Ph.D., Laboratory of Neurochemistry and Cellular Biology, Department of Biochemistry, Institute of Health Science, Federal University of Bahia Universidade Federal da Bahia Salvador, BA , 40.110-902, Brazil, Tel: 55-71 32838919; Fax: 55-71 32838884; E-mail: costasi@ufba.br, costasl2011@gmail.com

Received February 07, 2014; Accepted February 09, 2014; Published February 12, 2014

Citation: Costa SL (2014) Antiglioma Potential of Flavonoides. J Bioanal Biomed 6: e124. doi:10.4172/1948-593X.1000e124

Copyright: @ 2014 Costa SL. This is an open-access article distributed under the terms of the Creative Commons Attribution License, which permits unrestricted use, distribution, and reproduction in any medium, provided the original author and source are credited. 


\begin{tabular}{|c|c|c|c|c|}
\hline Flavonoid or Extract & Origin & Human cell Lines & Biological Effects & Reference \\
\hline Flavonoid rich extract & Scutellariabaicalensis & Glioma cell lines & Growth inhibition and apoptosis & Scheck et al., 2006 \\
\hline Flavonoid rich extract & Vaccinia macrocarpa & U87 & Growth inhibition & Ferguson et al., 2006 \\
\hline $\begin{array}{l}3,3^{\prime}, 4^{\prime}, 5,6-\text {-Pentahydroxyflavone } \\
\text { (quercetina; rutinaglycone) }\end{array}$ & $\begin{array}{l}\text { Many plants (i.ecapparisspinosa, } \\
\text { Anethumgraveolens, Allium cepa) } \\
\text { commercialized }\end{array}$ & $\begin{array}{l}\text { LN229, U87MG, } \\
\text { T98G, GL-15 }\end{array}$ & Apoptosis through oxidative stress & Sharma et al., 2007 \\
\hline $\begin{array}{l}\text { 3',4',5,7-tetrahyidroxyflavone } \\
\text { (kaempferol) }\end{array}$ & $\begin{array}{l}\text { Many plants (i.e Allium, Delphinium, } \\
\text { Camellia) commercialized }\end{array}$ & & & \\
\hline Silibinin & Sylibummarianum & U251MG & $\begin{array}{l}\text { Sensibilizated human glioma cells to } \\
\text { TRAIL-mediated apoptosis }\end{array}$ & Son et al., 2007 \\
\hline $\begin{array}{l}\text { 5-hydroxy-7,4-dimethoxyflavone, } \\
\text { casticin, apigenin, and penduletin }\end{array}$ & Croton betulaster & GL-15 & $\begin{array}{l}\text { Growth inhibition Down regulation of } \\
\text { TGF- } \beta\end{array}$ & Freitas et al, 2011 \\
\hline Penduletin & & GL-15 & Astroglial differentiation & Noneste et al., 2011 \\
\hline Rutin & Dimorphandamollis & GL-15 & $\begin{array}{l}\text { Growth inhibition and apoptosis, } \\
\text { Astroglial differentiation Down } \\
\text { regualation of TGF- } \beta 1 \text { and VEGF }\end{array}$ & $\begin{array}{l}\text { Santos et al., 2011, } \\
\text { Noneste et al., } 2011, \\
\text { Freitas et al, } 2011\end{array}$ \\
\hline Hinokiflavone-8methyl-crisilliol & & U251MG; TG-1 & Growth inhibition & Costa et al., not published \\
\hline
\end{tabular}

( ${ }^{*}$ Human cell lines derived from primary and recurrent brain tumors)

Table 1: Effect of flavonoids obtained from different plants in glioma cells.
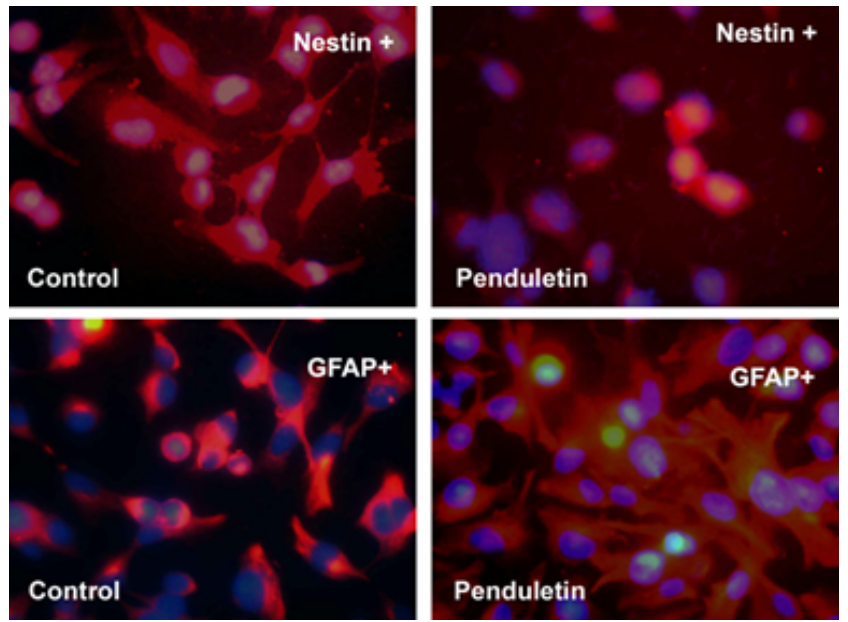

Figure 1: Nestin and GFAP immunocytochemistry in GL-15 human glioblastoma cells cultures in control conditions (vehicle $0.5 \%$ DMSO) or exposed to flavonoid penduletin.

component of immature astrocytes and GFAP is a major protein of astrocytes intermediate filaments and a specific marker for these cells. Moreover, studies have reported that increase in GFAP content is related to differentiation in malignant gliomas $[17,18]$ also investigated the differentiation potential of many flavonoids and found that the rutin aglycone quercetin induced differentiation of rat neural PC12 cells but not rutin, suggesting that structural determinants were needed for differentiation activity induced by flavonoids. Finally the recent findings that astrocytes and microglia are targets for the flavonoid rutin, inducing activation and even the release of trophic factors such as TNF-alpha and nitric oxide $[19,20]$ may lead to the development of new therapy protocols based on stimulation of glial cells response against glioblastomas.

\section{References}

1. Louis DN, Ohgaki H, Wiestler OD, Cavenee WK, Burger PC, et al. (2007) The 2007 WHO classification of tumours of the central nervous system. Acta Neuropathol 114: 97-109.

2. Stupp R, Mason WP, van den Bent MJ, Weller M, Fisher B, et al. (2005) Radiotherapy plus concomitant and adjuvant temozolomide for glioblastoma. N Engl J Med 352: 987-996.
3. Gerstner ER, Duda DG, di Tomaso E, Sorensen G, Jain RK, et al. (2007) Antiangiogenic agents for the treatment of glioblastoma. Expert Opin Investig Drugs 16: 1895-1908.

4. Yang K, Lamprecht SA, Liu Y, Shinozaki H, Fan K, et al. (2000) Chemoprevention studies of the flavonoids quercetin and rutin in normal and azoxymethanetreated mouse colon. Carcinogenesis 21: 1655-1660.

5. Youdim KA, Dobbie MS, Kuhnle G, Proteggente AR, Abbott NJ, et al. (2003) Interaction between flavonoids and the blood-brain barrier: in vitro studies. $J$ Neurochem 85: 180-192.

6. Youdim KA, Shukitt-Hale B, Joseph JA (2004) Flavonoids and the brain interactions at the blood-brain barrier and their physiological effects on the central nervous system. Free Radic Biol Med 37: 1683-1693.

7. Ferguson PJ, Kurowska EM, Freeman DJ, Chambers AF, Koropatnick J (2006) In vivo inhibition of growth of human tumor lines by flavonoid fractions from cranberry extract. Nutr Cancer 56: 86-94.

8. Braganhol E, Zamin LL, Canedo AD, Horn F, Tamajusuku AS, et al. (2006) Antiproliferative effect of quercetin in the human U138MG glioma cell line. Anticancer Drugs 17: 663-671.

9. Sharma V, Joseph C, Ghosh S, Agarwal A, Mishra MK, et al. (2007) Kaempferol induces apoptosis in glioblastoma cells through oxidative stress. Mol Cancer Ther 6: 2544-2553.

10. Son YG, Kim EH, Kim JY, Kim SU, Kwon TK, et al. (2007) Silibinin sensitizes 
human glioma cells to TRAIL-mediated apoptosis via DR5 up-regulation and down-regulation of c-FLIP and survivin. Cancer Res 67: 8274-8284.

11. Freitas S, Costa S, Azevedo C, Carvalho G, Freire S, et al. (2011) Flavonoids inhibit angiogenic cytokine production by human glioma cells. Phytother Res 25: $916-921$.

12. Janbaz KH, Saeed SA, Gilani AH (2002) Protective effect of rutin on paracetamol- and CCl4-induced hepatotoxicity in rodents. Fitoterapia 73: 557563.

13. Stoclet JC, Chataigneau T, Ndiaye M, Oak MH, El Bedoui J, et al. (2004) Vascular protection by dietary polyphenols. Eur J Pharmacol 500: 299-313.

14. Santos BL, Silva AR, Pitanga BPS, Sousa CS, Grangeiro MS, et al. (2011) Antiproliferative, proapoptotic and morphogenic effects of the flavonoid rutin on human glioblastoma cells. Food Chem 127:404-411.

15. Patru C, Romaou L, Philipe C, Varlet P, Coulombel L, et al. (2010) Caracterization of tumor initiating cells from human malignan glio-neuronal tumors ans their regulation by multiple gpcrs. BMC Cancer 10: 66-78.
16. Nones J, Stipursky J, Costa SL, Gomes FC (2010) Flavonoids and astrocytes crosstalking: implications for brain development and pathology. Neurochem Res 35: 955-966.

17. Rutka JT, Hubbard SL, Fukuyama K, Matsuzawa K, Dirks PB, et al. (1994) Effects of antisense glial fibrillary acidic protein complementary DNA on the growth, invasion, and adhesion of human astrocytoma cells. Cancer Res 54 3267-3272.

18. Sagara Y, Vanhnasy J, Maher P (2004) Induction of PC12 cell differentiation by flavonoids is dependent upon extracellular signal-regulated kinase activation. $J$ Neurochem 90: 1144-1155.

19. Silva AR, Pinheiro AM, Souza CS, Freitas SR, Vasconcellos V, et al. (2008) The flavonoid rutin induces astrocyte and microglia activation and regulates TNF-alpha and NO release in primary glial cell cultures. Cell Biol Toxicol 24 $75-86$

20. Costa SL (2012) Flavonoids as modulators of glia/glioma interaction: role of inflammatory cytokines and MEC/MMP expression. PHARMA 2012 - 2nd International Conference \& Exhibition on Pharmaceutical Regulatory Affairs. Hyderabad, India. 